\title{
CONTEMPORARY SLAVERY IN BRAZIL: WHAT HAVE COMPANIES (NOT) DONE TO PREVENT IT?
}

\author{
TOBIAS COUTINHO PARENTE \\ Universidade de São Paulo (USP), São Paulo - SP, Brazil.
}

ANGELA CHRISTINA LUCAS

Centro Universitário FEI, São Paulo - SP, Brazil.

\section{RAFAELA ALMEIDA CORDEIRO}

Escola Superior de Propaganda e Marketing (ESPM), São Paulo - SP, Brazil.

To cite this paper: Parente, T. C., Lucas, A. C., \& Cordeiro, R. A. (2017). Contemporary slavery in Brazil: what have companies (not) done to prevent it? Revista de Administração Mackenzie, 18(4), 39-64. doi 10.1590/1678-69712017/administracao.v18n4p39-64 


\section{ABSTRACT}

Purpose: Identify the practices adopted by companies to monitor and prevent contemporary slavery and the elements that differentiate companies that adopt monitoring practices for prevention of slavery and those that do not.

Originality/value: This question is investigated from the perspective of management, reputation and institutional environment literature, pointing out the reasons that lead companies to adopt or avoid contemporary slavery.

Design/methodology/approach: We used secondary data from Melhores Empresas para Você Trabalhar [Best Companies to Work] 2014 on 305 companies, which filled a questionnaire about their management practices and policies to monitor the working conditions in the supply chain in relation to the use of slave labor.

Findings: Results show that the practice adopted by most companies is related to sanctions on contracted suppliers who are caught using slave labor, and the element that differentiates groups of companies that adopt monitoring practices from those that do not is the fact of whether they are or not signatories of the National Pact to Eradicate Slave Labor [Pacto Nacional pela Erradicação do Trabalho Escravo].

\section{KEYWORDS}

Contemporary slavery. Management practices. Corporate reputation. Institutional environment. Slave labor.

\section{INTRODUCTION}

In the age of knowledge management, the persistence of slavery causes shock, indignation and questionings. According to the International Labor Organization (Organização Internacional do Trabalho - OIT, 2014), about 
21 million people are in forced labor, trafficked, held in debt bondage or work in slave-like conditions in the world. It is estimated that the profit obtained by companies that engage in this criminal practice is around US $\$ 150$ billion per year. Most of this illegal profit comes from the AsiaPacific region, where almost 12 million of these workers are concentrated, representing $56 \%$ of the total worldwide. This region is characterized by fragile labor laws, low educational level of the population and low production costs.

In Brazil, according to the Global Slavery Index (2016), around 160,000 people work under slavery. Although this number is high, the country has been prominent in the development of actions to prevent and combat slave labor. One of the main initiatives to curb this practice is the Blacklist of Slave Labor, in which employers caught submitting workers to conditions analogous to slavery are registered. Individual and legal entities registered in the list have access to financing and credit suspended, and are blocked by the signatories of the National Pact to Eradicate Slave Labor, called "Pacto" in Brazil.

With increased surveillance, striking cases have been recurrent. Companies such as Zara, Le Lis Blanc and Lojas Renner were caught subcontracting factories that kept workers in slave-like conditions, including child labor, exhausting shifts of up to 16 hours and curtailment of freedom. In these surveillance operations, more than 100 people were released.

The theme has aroused interest of researchers both nationally and internationally because it is considered emerging and interdisciplinary, and still lacks a theoretical framework. Thus, different authors have investigated the issue of contemporary slavery in the areas of public policy (Antero, 2008; Monteiro \& Fleury, 2014), consumer behavior and corporate social responsibility (Gupta \& Hodges, 2012; Veludo-deOliveira, Mascarenhas, Tronchin, \& Baptista, 2014), ethics (Dahan \& Gittens, 2010), and management (Crane, 2013; Mascarenhas, GonçalvesDias, \& Baptista, 2015).

In the management area, the discussion of contemporary slavery as a management practice was initiated by the work of Crane (2013) and Mascarenhas et al. (2015), both of which made substantive theoretical contributions. Crane (2013) analyzes the macro (industrial, socioeconomic, geographic, cultural and regulatory) and micro (inherent management capacities for the maintenance of slavery) contexts to suggest seven propositions about the necessary conditions to practice slavery and reveal possible avenues for empirical research. Mascarenhas et al. (2015), through 
a qualitative analysis, provide evidence that corroborates and amplifies Crane's propositions (2013) in the Brazilian context, and launches a research agenda with topics that allow the understanding of slave labor as a management practice.

In this context, this paper seeks to amplify the discussion initiated by Crane (2013) and Mascarenhas et al. (2015). While most of the researches sought to understand and assess the incidence of slave labor and the characteristics of its stakeholders, the focus of the study reported in this paper is to present an overview of the monitoring and prevention practices of contemporary slavery adopted by companies that seek to be the best to work for in Brazil. The assumption is that, just as there are factors that lead to the existence of contemporary slavery, there is another set of factors that make companies avoid this practice, since most of them would have more disadvantages than gains by engaging in this criminal practice, such as major damage to their reputation (Gardberg \& Fombrun, 2006; Powell \& Skarbek, 2006) and institutional pressures (Dimaggio \& Powell, 1983; Scott, 2001).

The objectives of this study are: 1 . to identify which practices are being adopted by companies to monitor and prevent the use of slave labor, and 2 . to identify the elements that differentiate groups of companies that do or do not adopt monitoring practices to prevent slave labor. Therefore, we used secondary data from Melhores Empresas para Você Trabalhar [Best Companies to Work] (MEPT), composed of 305 companies, which were analyzed from the perspective of contemporary slavery as practice management and institutional and reputational aspects.

\section{LITERATURE REVIEW}

In this section, we present the main concepts of slavery, a brief history of labor inspection in Brazil, and a discussion about the context in which contemporary slavery happens as a management practice.

\subsection{WHAT IS CONTEMPORARY SLAVERY?}

There is still no consensus on the definition of slave labor, more commonly referred to as "conditions analogous to slavery." The term has been conceptualized based on socioeconomic, cultural and legal contexts, covering different illegal activities, such as forced labor, human trafficking, sexual exploitation and child labor (Bales, 2005; Crane, 2013; OIT, 2014). 
According to Bales and Robbins (2001), the researchers' intention is to create a long-lasting definition and to consider the different contexts in which slavery occurs, and ultimately to make international agreements based on the same classification and stipulate universal practices for prevention. For the authors, three aspects characterize contemporary slavery: 1 . possession of one individual by another; 2 . appropriation of the workforce; and 3. the imposition of these conditions through violence and coercive mechanisms.

In Brazil, the Ministry of Labor and Employment (Ministério do Trabalho e Emprego - MTE, 2011) qualifies slave labor based on four elements: 1, curtailment of liberty; 2 . submission of the worker to degrading conditions; 3. submission of the employee to exhaustive work; and 4. forced labor. Curtailment of freedom involves ostensible surveillance in the workplace, restriction of the worker's movement and retention of his or her personal documents (Miraglia, 2008). Degrading conditions occur when the employer does not offer adequate working conditions and guarantees of the worker's health and safety (MTE, 2011). Exhaustive work is related to work that exceeds the physical limits of the individual (Viana, 2006). Finally, forced labor is related to non-spontaneous labor and/or being under threat, with restriction of the worker's freedom, detention of his wages or documents, and his retention through fraudulent debt (OIT, 2005).

In general terms, slave labor is a practice contrary to decent work that is shaped by remuneration, conditions of freedom, equity, and security, guaranteeing a decent life for the worker (Moro Junior, 2011). A higher incidence of contemporary slavery is found in: sectors with low legitimacy and low value in the productive chain, labor intensive and unskilled activities, difficult access regions, areas with low socioeconomic development, fragile institutional environments, and workplaces that lack supervision (Crane, 2013; Phillips \& Sakamoto, 2012).

Thus, in Brazil, the practice of slave labor is more pronounced in rural areas where agriculture, livestock, wood extraction, and charcoal predominate. It is estimated that most workers involved in these activities are illiterate, do not have official documents (birth certificate, for example) and come from areas of extreme poverty, such as the states of Maranhão and Piauí (Monteiro \& Fleury, 2014). However, although slave labor is especially common in rural areas, in recent years, there has been an increase in urban areas as well. In 2013, most of the rescued workers were involved in construction and textile industry activities (Mascarenhas et al., 2015). 


\subsection{THE INSPECTION OF LABOR IN BRAZIL AND THE FIGHT AGAINST SLAVERY}

The Brazilian system of labor inspection has been recognized for fighting against slavery. Since the creation of the Ministry of Labor, Industry and Commerce in 1930, the improvement of regulation, the intensification of inspections and the encouragement of the adherence of entrepreneurs to the laws that protect workers' rights have been observed (Cardoso \& Lage, 2005).

The country's commitment to eradicating slave labor took shape in the 1960s and was expanded in the 1990s. During this period, Brazil signed important international legal instruments that establish the commitment of the signatory countries to combat slavery by means of legislation that imposes sanctions in the event that forced labor is found, guaranteeing satisfactory working conditions and combating all types of servitude and slavery (MTE, 2011).

In the early 1990s, progress was made in combating slavery with the creation of new federal programs, such as the Programa de Erradicação do Trabalho Forçado e do Aliciamento de Trabalhadores [Program for the Eradication of Forced Labor] (Monteiro \& Fleury, 2014). However, it was in the following decade that Brazilian efforts to combat slave labor gained strength and international prominence. In 2003, the federal government launched the Plano Nacional para a Erradicação do Trabalho Escravo [National Plan for Eradication of Slave Labor] and presented strategic actions for the eradication of all contemporary forms of slavery.

From that moment on, initiatives to combat slave labor were intensified through the mobilization of civil society, the federal government and NonGovernmental Organizations (NGOs). One of them is the Cadastro de Empregadores (also known as "Lista Suja"), created in 2003 and maintained by the MTE and the Secretariat for Human Rights. Physical and legal persons caught using slave labor are registered in this list. Another important initiative is the Pacto, launched in 2005, coordinated and monitored by Ethos Institute, Instituto Observatório Social, NGO Repórter Brasil and the International Labor Organization. The initiative aims to prevent Brazilian society from selling products from suppliers that use slave labor (Repórter Brasil, 2015). These two instruments complement each other insofar as the signatories to the Pacto affirm their commitment to block suppliers registered on Lista Suja.

The partnership among federal institutions, NGOs and other social actors has promoted new discussions on the subject, helped to publicize 
enforcement actions and made public the name of companies involved in labor exploitation. Although in international conventions Brazil is a prominent country in the adoption of measures to fight slave labor practices, there are still a large number of people subject to these conditions in the country - it is estimated that 161,000 people work under slavery (Global Index Slavery, 2016).

The following section is a discussion of contemporary slave labor from the perspective of management literature, reputation and institutional environment.

\subsection{CONTEMPORARY SLAVERY AS A MANAGEMENT PRACTICE}

The management literature has paid little attention to the phenomenon of slavery, either in historical analyses of the period in which such practice was accepted or in investigations of contemporary slavery (Cooke, 2003). In this discussion, resistance has been observed both by researchers in the area of management, who seem not to give importance to the influence that the slave period had on the development of the field of management, as by entrepreneurs, who argue that they do not have the capacity to follow their productive chains because they are ample and because of the lack of mechanisms to supervise the activities of their suppliers (Rocha, 2009).

In order to fill this gap, Crane (2013) proposes a model based on institutional theory and the literature on strategic capabilities, termed "modern slavery as a management practice." The work elucidates the necessary conditions of the macro environment for slavery to persist and the capacities of the companies, at the micro level, determinants for slavery to flourish. The author explores the competitive and institutional situations that may lead to slavery, how companies isolate institutional pressures and articulate to maintain such practices, and how the conditions that allow slave labor to be maintained and/or shape. However, an issue not raised by the author seems to be important for discussion: the reasons that may lead companies to adopt practices for monitoring and preventing slave labor - for example, to shield reputation.

A company's reputation may be threatened in many different ways: product failure, social responsibility gaps, misconduct, poor performance, loss of public support, and others (Greyser, 2009). The use of slave labor constitutes a social responsibility gap sort of misconduct. It has been common for companies caught using slave labor to adopt a posture of denial. On the other hand, there are examples of companies that have fallen under public 
scrutiny, have had their reputation shaken, and from that scenario have reshaped their work programs in order to recover their image - for example the cases of Gap Inc. and Nike (Ansett, 2007). That is why developing a transparent and accountable strategy can bring rewards such as reputation increase, license to operate in different locations, retention of employees, and innovative process development, among others (Gardberg \& Fombrun, 2006). Certification standards such as SA 8000 - which encourages the development and application of socially acceptable practices in the workplace - are examples of how companies are committed to acting responsibly, avoiding social responsibility gaps and shielding their reputation.

Ethical dilemmas have always been present in organizations, but expanding access to information has made such dilemmas public and society has demanded greater corporate transparency. As a result, it is more common nowadays for companies to be very concerned with the management of their reputational capital (Gardberg \& Fombrun, 2006; Machado Filho \& Zylbersztajn, 2004) and the way they operate in the numerous localities where they are present (Jamali \& Neville, 2011; Matten \& Moon, 2008).

In this sense, just as there is a combination of factors internal and external to the organizations that lead to a situation favorable to the flourishing of contemporary slavery (Crane, 2013), there is another set of aspects that makes companies avoid this practice. The reputational issue is one of them: being associated with contemporary slavery creates damage to the organization that may be irreversible. Another factor that discourages this type of practice is the institutional environment in which the company operates: when there are solid institutions, companies are forced to adopt behaviors compatible with the work practices pre-established by the institutional environment (North, 1990).

Based on this discussion, the following section presents characteristics that may lead companies to use or avoid slave labor.

\subsubsection{WHY IT EXISTS}

Some environmental factors favor the existence of slave labor. According to Barzel (1977), slavery existed only in societies in which rules allowed an environment favorable to productivity gains through such practice. The combination of a fragile institutional environment with a society of low economic development was, and continues to be, a space conducive to the super-exploitation of workers (Crane, 2013; Phillips \& Sakamoto, 2012). Thus, in regions where the rules of the game are not enforced, agents can organize, 
collectively or otherwise, in the way that will best provide them with economic profitability. Associated with this, if the region is characterized by poverty and a history of permissiveness with this form of exploitation, there may be a greater probability of slave labor. These conditions support what Crane (2013) called "institutional deviation", in which the institutional forces that make slave labor illegitimate are deviated from by external and internal contingencies.

In this context, Crane (2013) argues that slavery is an attempt to reduce prices through a fundamental resource (labor) using illegitimate means. The key to understanding modern slavery as a management practice is to determine how companies implement illegitimate methods to reach this low price, and when they do, how they manage to survive. Based on Scott's (2001) institutional theory, the author identifies a set of factors that propitiate the use of slave labor by organizations; such factors are related to the industrial, socioeconomic, geographic, cultural and regulatory contexts. The characteristics of each of these dimensions are: 1 . industrial context: sectors that use labor intensive practices and unskilled labor, generate low value in the production chain and face problems of legitimacy; 2 . socioeconomic context: places where there is high level of unemployment and poverty, and low educational level; 3. geographical context: difficult to access regions that cause social isolation of the worker; 4 . cultural context: cultures that accept coercive working relationships and inequality; 5. regulatory context: environment where there are fragile institutions and corporate governance, and where there is no focus on the fight against slave labor.

In Brazil, Mascarenhas et al. (2015) present evidence that the set of external conditions that lead to contemporary slave labor occurs in a way that adheres to the model proposed by Crane (2013). In order to extend the discussion, the authors propose a research agenda with research questions involving the micro, meso and macro levels. One of them is to raise the implications of the public and private regulatory context for the eradication of slave labor. This question is inserted in the proposal for the current study and is discussed in more detail in section 5, where we present an analysis of the adoption of practices of prevention of slave labor by the signatory companies of Pacto.

\subsubsection{WHY COMPANIES AVOID IT}

What characterizes companies that seek preventive practices for contemporary slave labor? We assume that most companies would not be in an advantageous position if they practiced the institutional deviation identified 
by Crane (2013). That is why there is a set of factors that make companies not engage in illegal practices, even if through third parties. Among them, we highlight the reputational aspect and institutional environment.

According to Machado Filho (2002), organizations in which behavior is considered questionable - whether in the economic, ethical or legal sense, intentionally or not - can call people's attention in a negative way, causing damage to their image and compromising their survival. Considering technological advances and the ease and speed with which information can now be shared, the risk of exposure due to questionable behavior is much greater in the 21 st century. There is a greater mobilization of people for social causes (including labor), manifested through boycotts and demands (Powell \& Skarbek, 2006).

Thus, reputational issues gain weight in the strategic equation of organizations (Gardberg \& Fombrun, 2006). Even if the company acts in accordance with the economic, ethical and legal standards in force in society, its partners may not do so and this tends to fall on the shoulders of that company. Tracking suppliers' practices seems to be an efficient way of avoiding damage to reputational capital, which affects (positively or negatively) market value, ability to negotiate contracts, and operating costs, directly and indirectly impacting competitive advantage (Doh, Howton, Howton, \& Siegel, 2010). In view of such issues, we believe that the reputational aspect can be a remedy in monitoring and preventing the exploitation of slave labor, since it encourages companies to care about their actions and those of their partners.

In addition to the leverage that companies' concern about their reputation grants, the perspective of the institutional environment can also encourage the monitoring and prevention of contemporary slave labor. According to institutional theory, organizations adopt specific behaviors to access resources that enable the achievement of their objectives; however, they must follow certain rules. Such rules define the institutional environment, which may be fragile or strong (North, 1990).

Thus, organizations would act according to the rules of the game, which are dictated by institutions. Institutions, therefore, have the role of guaranteeing the rights established by social relations over time. When they succeed in enforcing what is written and agreed between the parties, they fulfill their role of reducing uncertainty and ensuring a environment conducive for economic development (North, 1990). These characteristics constitute a solid institutional environment. On the other hand, when there is no guarantee that the institutions of a society can enforce agreements about 
employer-employee relations, there is a fragile institutional environment. In this scenario, there is a greater chance of institutional deviation.

In this sense, the institutional environment can be considered, for the analysis of modern slavery, as "a double-edged sword": at the same time as it can facilitate agents' behavior deviation, it can also create conditions in which this is not likely to occur. In sum, the high cost of reputational capital and a strong institutional environment are factors that can reduce the probability of exploitation of slave labor.

\section{METHODS}

Data from MEPT were used in this study. The subscription process is open and voluntary for the companies operating in Brazil. Based on the organizational climate and the adopted people management practices and policies, a list of the best 150 companies to work for in the country is published. The list is currently in its 21 st edition and has been recognized as a trustworthy ranking regarding corporate reputation (Fombrun, 2007).

Employees from participating companies are invited to answer a questionnaire to measure their perception regarding several aspects of the work environment. At the same time, companies, represented by human resources managers, answer a questionnaire about the companies' HR profile and people management practices and policies, which are organized into the following themes: strategy and management, leadership, remuneration, career, health, development, and organizational citizenship.

\subsection{DATA COLLECTION AND SAMPLE SELECTION}

Each year, MEPT research includes a special theme to be investigated. In 2014's edition, contemporary slavery was investigated - nine questions regarding monitoring practices of work conditions in the supply chain were included in the research. The questions were developed from Pacto and from extant study of contemporary slavery, and were organized into three groups: 1. penalty actions - when the company only acts to suspend the contracted suppliers caught, but does not take an active role in the fight against slavery (V1 and V2); 2. monitoring actions - when the company monitors and inspects all of its supply chain in order to identify slavery-like practices (V3, V4 and V9); and 3. actions of prevention - when the company supports and maintains training programs, and promotes information regarding slavery to 
its employees and suppliers (V5,V6,V7 and V8). The variables are presented in Table 1.

The criteria for companies' participation in the research were to have at least 200 employees - excluding contractors and interns - and to be operating in the national or international market for at least five years. In total, 327 companies participated; 305 fully answered the questionnaire and composed the sample of this study. The authors chose to analyze the complete list of the subscribed companies to assess if there were differences between companies classified in the 150 best list and the others regarding the adoption of monitoring practices for the prevention against slave labor.

\section{(Table 1) \\ STATEMENTS TO IDENTIFY MONITORING PRACTICES OF THE SUPPLY CHAIN REGARDING THE USAGE OF SLAVE LABOR}

\begin{tabular}{ll}
\hline Variables & Statements \\
\hline V1 & $\begin{array}{l}\text { Do established contracts with all suppliers foresee penalties in case slavery-like } \\
\text { practices and/or child labor is verified at any level of the supply chain? }\end{array}$ \\
\hline V2 & $\begin{array}{l}\text { Does the company disclose to society when it needs to suspend contracts with } \\
\text { suppliers that explore manpower with slavery-like practices and/or child labor at any } \\
\text { level of the supply chain? }\end{array}$ \\
\hline V3 & $\begin{array}{l}\text { Does the company perform an internal audit to verify if there is exploration of } \\
\text { manpower with slavery-like practices and/or child labor at any level of the supply } \\
\text { chain? }\end{array}$ \\
\hline Vo & $\begin{array}{l}\text { Does the company perform an external audit to verify if there is exploration of } \\
\text { chain? }\end{array}$ \\
\hline V6 & $\begin{array}{l}\text { Does the company request that its suppliers also performs audit to verify if there } \\
\text { is an exploration of manpower with slavery-like practices and/or child labor at any } \\
\text { level of the supply chain? }\end{array}$ \\
\hline $\begin{array}{l}\text { Does the company perform training actions alongside its employees and } \\
\text { contractors to operate in the monitoring of the supply chain? }\end{array}$ \\
\hline $\begin{array}{l}\text { Does the company support actions of social and productive reintegration of } \\
\text { employees in its supply chain that are found in slavery-like conditions and/or child } \\
\text { labor? }\end{array}$
\end{tabular}

(continue) 


\section{(Table 1)}

STATEMENTS TO IDENTIFY MONITORING PRACTICES OF THE SUPPLY CHAIN REGARDING THE USAGE OF SLAVE LABOR

\begin{tabular}{ll}
\hline Variables & Statements \\
\hline v8 & $\begin{array}{l}\text { Does the company support actions of information to the employees of its } \\
\text { supply chain that are vulnerable to grooming of slavery-like practices and/ } \\
\text { or child labor? }\end{array}$ \\
\hline v9 & $\begin{array}{l}\text { Does the company evaluate the results of its monitoring performance } \\
\text { regarding the labor conditions in its supply chain? }\end{array}$ \\
\hline
\end{tabular}

Source: MEPT (2014).

\subsection{SAMPLE DESCRIPTION}

Chart 1 shows the sample description regarding: the source of capital, localization, the number of workplaces and employees, business sector and whether the company is a signatory of Pacto. The business sector was classified into "intensive manpower sector" or "non-intensive manpower sector" according to the criteria proposed by Crane (2013) and Mascarenhas et al. (2015), which defined intensive manpower as activities related to: agriculture, livestock, construction, clothing and textile, charcoal and wood cutting.

\section{(Chart 1)}

\section{SAMPLE DESCRIPTION}

\begin{tabular}{|c|c|c|c|c|c|}
\hline \multicolumn{2}{|l|}{ Capital source } & \multicolumn{2}{|c|}{ Pacto signatory } & \multicolumn{2}{|l|}{ Sector } \\
\hline National & $72.2 \%$ & Yes & $16.1 \%$ & With intensive manpower & $16.7 \%$ \\
\hline Multinational & $27.8 \%$ & No & $83.9 \%$ & $\begin{array}{l}\text { Without intensive } \\
\text { manpower }\end{array}$ & $83.3 \%$ \\
\hline \multicolumn{2}{|l|}{ Region } & \multicolumn{2}{|c|}{ Workplaces } & \multicolumn{2}{|l|}{ Number of employees } \\
\hline São Paulo & $50.5 \%$ & 01 & $15.4 \%$ & Until 500 & $34.4 \%$ \\
\hline South & $20.7 \%$ & 02 to 04 & $27.5 \%$ & From 501 to 1500 & $27.1 \%$ \\
\hline
\end{tabular}

(continue) 


\section{(chart 1)}

SAMPLE DESCRIPTION

\begin{tabular}{ll|ll|ll}
\hline ES/MG/RJ & $14.1 \%$ & 05 to 16 & $31.5 \%$ & Above 1500 & $38.4 \%$ \\
\hline Center-West & $7.9 \%$ & Above 16 & $25.6 \%$ & & \\
\cline { 1 - 3 } North/Northeast & $6.9 \%$ & & & \\
\hline
\end{tabular}

Source: Elaborated by the authors.

\section{RESULTS}

Most companies $(n=209)$ adopt at least one of the monitoring practices of work conditions in the supply chain, while $31.5 \%(n=96)$ do not adopt any practices. More than $50 \%$ of the companies sign contracts with suppliers providing for sanctions in case of labor exploitation under conditions analogous to slavery or child labor. However, a few adopt policies that provide support to workers who are in these conditions: $15.7 \%$ support informational actions for workers in this situation and $10.2 \%$ support action to socially reintegrate these workers. The data are shown in Chart 2.

The number of actions that companies perform was also analyzed. In Graph 1, it can be observed that 88 companies that indicated having some practice for monitoring the work conditions in their supply chain engage in only one practice of the nine presented, whereas only eight companies engage in all of the practices surveyed. Of those who adopt only one practice, 62 companies foresee contractual sanctions against their suppliers. The average of 3.10 practices adopted by the companies shows that actions aimed at monitoring and preventing slave labor are still incipient—even among companies that seek to enter the list of best to work with.

According to the literature, characteristics of the companies and environment in which they are inserted (Crane, 2013; Mascarehas et al., 2015; Phillips \& Sakamoto, 2012) combined with reputational aspects (Gardberg \& Fombrun, 2006; Machado Filho \& Zylbersztajn, 2004) could lead organizations to take a different approach to the issue of contemporary slave labor. In order to assess whether that is the case, the companies were classified into analysis groups, presented in Chart 3. For each group, the average number of practices adopted by the companies was assigned and 
used to test the difference between groups by means of Analysis of Variance (ANOVA).

\section{(Chart 2)}

MONITORING PRACTICES ADOPTED BY COMPANIES (IN ORDER OF ADHERENCE)

\begin{tabular}{cc} 
Variables & \% Companies that adopt \\
\hline V1 & 53.8 \\
\hline V3 & 29.8 \\
\hline V6 & 27.9 \\
\hline V9 & 22.0 \\
\hline$V 4$ & 21.6 \\
\hline$V 5$ & 20.7 \\
\hline$V 8$ & 15.7 \\
\hline$V 2$ & 10.8 \\
\hline$V 7$ & 10.2 \\
\hline
\end{tabular}

Source: Elaborated by the authors.

\section{(Chart 3)}

\section{NUMBER OF PRACTICES PER COMPANY}

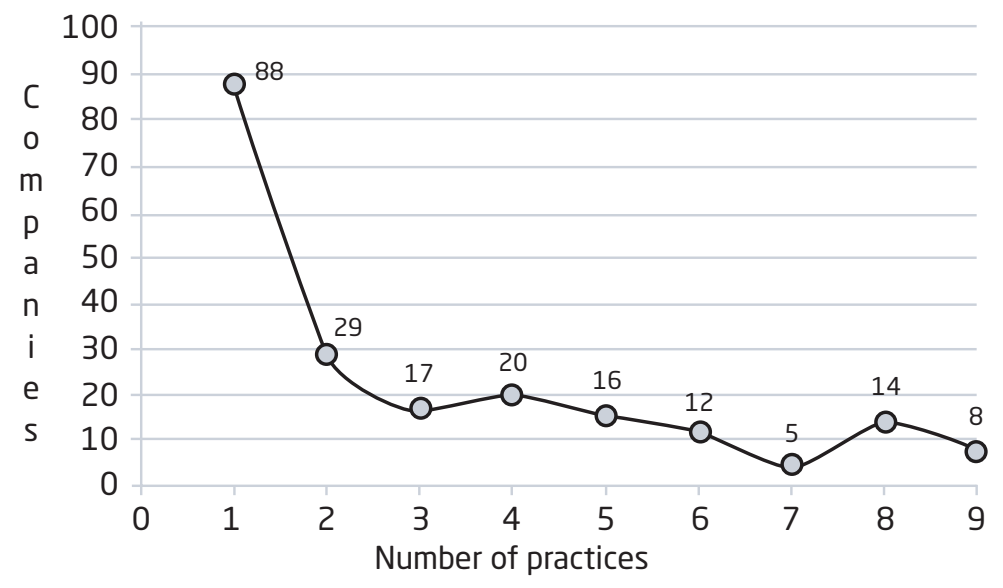

Source: Elaborated by the authors. 
Because there are a large number of companies that do not adopt any anti-slavery practices $(n=96)$, we chose to present the profile of this group. It is noted that many of these companies are listed as better to work with, and most of them are medium to large. The data are presented in Chart 4.

\section{(Chart 4)}

\section{ANALYSIS OF GROUPS' CLASSIFICATION}

\begin{tabular}{|c|c|c|c|c|c|}
\hline \multicolumn{6}{|c|}{ Analysis of groups } \\
\hline $\begin{array}{l}\text { With intensive } \\
\text { manpower }\end{array}$ & $\begin{array}{l}\text { Yes } \\
(3.12)\end{array}$ & $\begin{array}{l}\text { No } \\
(3.03)\end{array}$ & & & \\
\hline $\begin{array}{l}\text { Has a productive } \\
\text { process linked to its } \\
\text { final activity }\end{array}$ & $\begin{array}{l}\text { Yes } \\
(3.29)\end{array}$ & $\begin{array}{l}\text { No } \\
(2.97)\end{array}$ & & & \\
\hline $\begin{array}{l}\text { It is one of the } 150 \\
\text { best }\end{array}$ & $\begin{array}{l}\text { Yes } \\
(3.07)\end{array}$ & $\begin{array}{l}\text { No } \\
(3.14)\end{array}$ & & & \\
\hline Pacto signatory & $\begin{array}{l}\text { Yes } \\
(5.08)\end{array}$ & $\begin{array}{l}\text { No } \\
(2.49)\end{array}$ & & & \\
\hline Capital source & $\begin{array}{l}\text { National } \\
\text { (3.09) }\end{array}$ & $\begin{array}{l}\text { Multinational } \\
\text { (3.13) }\end{array}$ & & & \\
\hline $\begin{array}{l}\text { Number of } \\
\text { employees with } \\
\text { elementary } \\
\text { education }\end{array}$ & $\begin{array}{l}\text { Up to } 20 \% \\
(3.17)\end{array}$ & $\begin{array}{l}\text { More than } \\
20 \% \\
(2.66)\end{array}$ & & & \\
\hline $\begin{array}{l}\text { Number of } \\
\text { employees }\end{array}$ & $\begin{array}{l}\text { Up to } 500 \\
(2.73)\end{array}$ & $\begin{array}{l}501 \text { to } 1.500 \\
(3.50)\end{array}$ & $\begin{array}{l}\text { More than } 1.500 \\
(3.14)\end{array}$ & & \\
\hline Operating time & $\begin{array}{l}\text { Up to } 18 \text { anos } \\
(3.16)\end{array}$ & $\begin{array}{l}19 \text { to } 36 \text { years } \\
(3.27)\end{array}$ & $\begin{array}{l}37 \text { to } 53 \text { years } \\
(2.64)\end{array}$ & $\begin{array}{l}\text { More than } 53 \\
\text { anos } \\
(3.29)\end{array}$ & \\
\hline $\begin{array}{l}\text { Number of } \\
\text { Workplaces }\end{array}$ & $\begin{array}{l}01 \\
(2.61)\end{array}$ & $\begin{array}{l}02 \text { a } 04 \\
(3.66)\end{array}$ & $\begin{array}{l}05 \text { a } 16 \\
(2.89)\end{array}$ & $\begin{array}{l}\text { More than } 16 \\
(3.06)\end{array}$ & \\
\hline Region & $\begin{array}{l}\text { North/Northeast } \\
(2.80)\end{array}$ & $\begin{array}{l}\text { Center-west } \\
(3.22)\end{array}$ & $\begin{array}{l}\text { São Paulo } \\
(3.12)\end{array}$ & $\begin{array}{l}\text { ES/MG/RJ } \\
(3.21)\end{array}$ & $\begin{array}{l}\text { South } \\
(3.05)\end{array}$ \\
\hline
\end{tabular}

Source: Elaborated by the authors. 


\section{(Chart 5)}

COMPANIES THAT DO NOT ADOPT PRACTICES

\begin{tabular}{|c|c|c|c|c|c|}
\hline \multicolumn{6}{|c|}{ Analysis of 96 companies (\%) } \\
\hline $\begin{array}{l}\text { With intensive } \\
\text { manpower }\end{array}$ & $\begin{array}{l}\text { Yes } \\
(24.0 \%)\end{array}$ & $\begin{array}{l}\text { No } \\
(76.0 \%)\end{array}$ & & & \\
\hline $\begin{array}{l}\text { Has a productive } \\
\text { process linked to } \\
\text { its final activity }\end{array}$ & $\begin{array}{l}\text { Yes } \\
(46.9 \%)\end{array}$ & $\begin{array}{l}\text { No } \\
(53.1 \%)\end{array}$ & & & \\
\hline $\begin{array}{l}\text { It is one of the } \\
150 \text { best }\end{array}$ & $\begin{array}{l}\text { Yes } \\
(44.8 \%)\end{array}$ & $\begin{array}{l}\text { No } \\
(55.2 \%)\end{array}$ & & & \\
\hline Capital source & $\begin{array}{l}\text { National } \\
(84.4 \%)\end{array}$ & $\begin{array}{l}\text { Multinational } \\
(15.6 \%)\end{array}$ & & & \\
\hline $\begin{array}{l}\text { Number of } \\
\text { employees with } \\
\text { elementary } \\
\text { education }\end{array}$ & $\begin{array}{l}\text { Up to 20\% } \\
(88.5 \%)\end{array}$ & $\begin{array}{l}\text { More than } \\
20 \% \\
(11.5 \%)\end{array}$ & & & \\
\hline $\begin{array}{l}\text { Number of } \\
\text { employees }\end{array}$ & $\begin{array}{l}\text { Up to } 500 \\
(32.3 \%)\end{array}$ & $\begin{array}{l}501 \text { to } 1500 \\
(21.9 \%)\end{array}$ & $\begin{array}{l}\text { More than } 1500 \\
(45.8 \%)\end{array}$ & & \\
\hline Operating time & $\begin{array}{l}\text { Up to } 18 \text { years } \\
(18.8 \%)\end{array}$ & $\begin{array}{l}19 \text { to } 36 \\
\text { years } \\
(28.1 \%)\end{array}$ & $\begin{array}{l}37 \text { to } 53 \text { years } \\
(29.2 \%)\end{array}$ & $\begin{array}{l}\text { More than } \\
53 \text { years } \\
(24.0 \%)\end{array}$ & \\
\hline $\begin{array}{l}\text { Number of } \\
\text { Workplaces }\end{array}$ & $\begin{array}{l}01 \\
(15.6 \%)\end{array}$ & $\begin{array}{l}02 \text { to } 04 \\
(27.1 \%)\end{array}$ & $\begin{array}{l}05 \text { to } 16 \\
(30.2 \%)\end{array}$ & $\begin{array}{l}\text { More than } \\
16 \\
(27.1 \%)\end{array}$ & \\
\hline Region & $\begin{array}{l}\text { North/ } \\
\text { Northeast } \\
(6.2 \%)\end{array}$ & $\begin{array}{l}\text { Center-west } \\
(6.2 \%)\end{array}$ & $\begin{array}{l}\text { São Paulo } \\
(52.1 \%)\end{array}$ & $\begin{array}{l}\text { ES/MG/RJ } \\
(14.6 \%)\end{array}$ & $\begin{array}{l}\text { South } \\
(20.8 \%)\end{array}$ \\
\hline
\end{tabular}

Source: Elaborated by the authors.

\section{DISCUSSION}

Results suggest that: i) in relation to the characteristics of the company and the environment, organizations that operate in conditions close to the conditions proposed by Crane (2013) and evidenced as adhering to the Brazilian scenario by Mascarenhas et al. (2015) do not seek to adopt more practices to monitor work conditions and prevent contemporary slave labor; 
ii) in relation to reputation, companies considered as better to work for do not adopt a distinct set of practices, whereas companies that are signatories of the Pacto present a set of practices that distinguish them from others in relation to monitoring their supply chain and prevention of slave labor.

With respect to the labor-intensive sectors considered more vulnerable to contemporary slave labor (Crane, 2013), it was expected that the companies involved in these activities would adopt a greater number of monitoring practices since they applied to be the best companies to work for. However, the 36 companies classified in this group (and claim to adopt some practice) did not relate a set of practices more consolidated than the others. This situation makes both the company and the worker vulnerable: if there is no concern of the organization for monitoring its supply chain, the chances of incidence of slave labor and sanctions of public and private entities become greater. On the labor side, is observed that the socially vulnerable position of employees in labor-intensive occupations (generally, people from areas with low socioeconomic development), combined with the employer's lack of action to prevent slave labor practices, expose them to a significant risk of being victims of slave labor practices.

In relation to the workers' vulnerability, we sought to gather evidence that there is an association between the socioeconomic conditions of the region's company and the adoption of the practices. For that, the HDI index of the region where the company headquarters are located and the number of employees with education up to elementary school were analyzed (these data were used because they are the only ones available for analysis). The 29 companies that have more than $20 \%$ of their workforce with this level of education do not have practices distinguishable from the others. There was also no significant correlation between company practices and the HDI of the host region. These findings suggest that the main problem may not be related to the worker linked to the company, but rather to subcontracted workers. Employees with employment relationships have rights guaranteed by labor legislation and the company is able to assure them since they are under its tutelage. However, when there are subcontracted workers with a low education level and from low-HDI regions raise, it is far more likely that slavery will flourish (Crane, 2013; Phillips \& Sakamoto, 2012).

The fact that companies have more employees and workplaces or are in less developed regions does not mean that they adopt more practices to monitor their supply chain. Companies with these characteristics should stick to such issues since their network of operations is complex and involves multiple cultural realities (Crane, 2013; Mascarenhas et al., 
2015). One possible explanation that deserves investigation concerns the political and legal structures responsible for labor inspection in Brazil. The geographic dimension of the country combined with the low number of inspection operations and the lack of knowledge of the worker give scope for the exploitation of contemporary slave labor (Monteiro \& Fleury, 2014).

In order to examine possible differences between the adoption of practices by companies based on their institutional environment, we chose to divide them according to the origin of capital (national or multinational). The multinational companies researched come from countries with a stronger institutional environment and greater economic and social development (the United States, European Union and Japan, for the most part). These companies may employ a superior set of practices for the prevention of contemporary slavery, since they respond to the legal standards of their country of origin; however, this was not verified. A possible explanation is that the Brazilian institutional fragility can lead companies to institutional deviation (Crane, 2013). Thus, the multinational companies would choose to adopt Brazilian standards instead of their countries' standards, keeping themselves level with the other companies researched. Another alternative is that contemporary slavery may not be a reality in the companies' countries of origin. Thus, they would not have developed practices to deal with the problem. However, such speculation lacks evidence.

The companies sampled applied to be recognized as the best to work for in Brazil and, through this classification, increase their reputational capital. However, this did not prove to differentiate those that adopted more from those that adopted fewer slave labor prevention practices; on average, companies had few practices.

On the other hand, the signatory companies of Pacto are distinguished from the others, presenting a higher average number of adopted practices (5.08 vs 2.49). This result may indicate that the Pacto has fulfilled its role of propagating good practices and generates two reflections. First, it is possible to understand that companies become signatories of the Pacto as a way to distinguish themselves from the others and create reputational capital that provides them with competitive gains. Secondly, it is possible that prevention by companies may not be caused only by the context in which they are inserted, but by intrinsic factors, such as employee and shareholder values and governance policy, among others, since this difference was not found in the companies chosen among the best to work for. Thus, the ethical and responsible performance of a company is not only due to external pressures and the search for reputational gains but also to internal aspects. Some 
possibilities that need to be evidenced in the empirical field, such as values of the executive directors, president, and shareholders, and organizational values shared by the organization's employees (Hemingway \& Maclagan, 2004).

\section{CONCLUDING REMARKS}

The purpose of this study was to present an overview about the monitoring and prevention practices of contemporary slavery adopted by companies that seek to be the best to work for in Brazil. Results show that: 1. the practice most adopted by the surveyed companies is to sanction contracted suppliers that are caught using slave labor; and 2. the element that most differentiates groups of companies that adopt monitoring practices to prevent slave labor from those that do not is whether or not they are signatories to the National Pact to Eradicate Slave Labor.

According to these results, it is observed that, as well as the public policies focused on the theme (Monteiro \& Fleury, 2014), companies that adopt anti-slavery practices are more concentrated on supervision and punishment of the chain agents than on prevention actions such as training and caring for the workers. However, repressive actions are necessary but insufficient for the eradication of contemporary slavery (Antero, 2007).

On the other hand, in a matter that has become relevant recently, there is still a lack of preparation of the companies to account to society, to restructure the productive chains and to create new bases of work. As well as the lack of preparation of companies to deal with the issue, studies show that, although society has played a fundamental role in consolidating corporate social responsibility by requiring transparency of companies in all their production processes (Becker-Olsen, Cudmore, \& Hill, 2005), many consumers do not have enough information about production conditions and believe that their behavior cannot change the company's behavior (Mohr, Webb, \& Harris, 2001) or that companies that had their suppliers caught exploiting slave labor may not necessarily be held liable for third parties' actions (Oliveira, Valadão-Junior, \& Miranda, 2013). In this context, the role of conventional and unconventional media has been fundamental for spreading information about slave labor and its prevention and expanding the discussion in different social spheres. According to Pedersen and Gwozdz (2014), companies will only change their corporate social responsibility practices if stakeholders (media, NGOs, consumer groups etc.) exert 
significant pressure, which does not tend to happen unless major players take such actions and are emulated by others.

This analysis leads us to two points of reflection. First, punishment, whether through fines or sanctions by the government against the companies or by the companies against their suppliers, is insufficient to eliminate contemporary slavery. It is necessary to disseminate preventive actions and create conditions for (re)inclusion of (potential) worker victims of this crime so that they do not become vulnerable, avoiding the cycle of the perpetuation of this practice. To this end, a solid institutional environment and public policies aimed at eradicating the practice should be the background for the creation of decent working conditions in all sectors. Second, rather than the characteristics of the company and industry, the role of stakeholders is fundamental to changing this scenario, especially the customers and shareholders, since they are the two main sources of financial resources of the company. As long as they do not view contemporary slavery as a substantial variable in their decision-making processes, to the point of not buying a product or investing in a company that engages in such practices (or has subcontractors who do), slave labor will tend to remain. Companies will only make fighting and preventing contemporary slavery an important part of their business agenda if there are real risks of loss of reputational capital, i.e., boycotting of their products by consumers and loss of shareholders.

Some important areas for future research to explore are: a) to understand the reasons why companies adhere to (or not) the Pacto and to verify if this choice is related to their leaders' values; b) to identify the reasons why companies do not adopt practices to monitor and prevent slave labor; c) to investigate issues related to consumer behavior - intention to buy, brand loyalty, intention to boycott - and their impact on companies' labor practices.

Regarding the limitations of the study, we highlight the following aspects: the data used come from a study that was not intended to answer our questions, even if it included questions related to the topic. In addition, it is important to recognize that we only have companies' word that they have adopted the practices they mentioned, but their actual adoption of those practices remains unverified for the most part. Finally, the study sample is limited to the participants in the MEPT survey - there are many other companies that need to be investigated, including those that have already been caught up in slave labor in their production chain. 


\section{DREFERENCES}

Ansett, S. (2007). Mind the gap: a journey to sustainable supply chains. Employee Responsibilities and Rights Journal, 19(4), 295-303. doi 10.1007/ s10672-007-9055-x.

Antero, S. A. (2007). Considerações sobre o trabalho escravo no Brasil do século XXI. Revista do Serviço Público, 58(4), 451-464. doi 10.21874/rsp. v58i4.183.

Antero, S. A. (2008). Monitoramento e avaliação do programa de erradicação do trabalho escravo. Revista de Administração Pública, 42(5), 791-828.

Bales, K. (2005). Understanding global slavery. Los Angeles: University of California Press.

Bales, K., \& Robbins, P. T. (2001). No one shall be held in slavery or servitude: a critical analysis of international slavery conventions. Human Rights Review, 2(2), 18-45. doi 10.1007/s12142-001-1022-6.

Barzel, Y. (1977). An economic analysis of slavery. Journal of Law and Economics, 20(1), 87-110. doi 10.1086/466893.

Becker-Olsen, K. L., Cudmore, B. A., \& Hill, R. P. (2005). The impact of perceived corporate social responsibility on consumer behavior. Journal of Business Research, 59(1), 46-53. doi 10.1016/j.jbusres.2005.01.001.

Cardoso, A., \& Lage, T. (2005). A Inspeção do trabalho no Brasil. Dados-Revista de Ciências Sociais, 48(3), 451-490. doi 10.1590/S0011-52582005000300001. Cooke, B. (2003). The denial of slavery in management studies. Journal of Management Studies, 40(8), 1895-1918. doi 10.1046/j.14676486.2003.00405.x.

Crane, A. (2013). Modern slavery as a management practice: exploring the conditions and capabilities for human exploitation. Academy of Management Review, 38(1), 49-69. doi 10.5465/amr.2011.0145.

Dahan, N. M., \& Gittens, M. (2010). Business and the public affairs of slavery: a discursive approach of an ethical public issue. Journal of Business Ethics, 92(2), 227-249. doi 10.1007/s10551-009-0151-8.

Dimaggio, P. J., \& Powell, W. W. (1983). The iron cage revisited: Institutional isomorphism and collective rationality in organizational fields. American Sociological Review, 48(2), 147-160. 
Doh, J. P., Howton, S. D., Howton, S. W., \& Siegel, D. S. (2010). Does the market respond to an endorsement of social responsibility? The role of institutions, information, and legitimacy. Journal of Management, 36(6), 1461-1485. doi 10.1177/0149206309337896.

Fombrun, C. J. (2007). List of lists: A compilation of international corporate reputation ratings. Corporate Reputation Review, 10(2), 144-153. doi 10.1057/ palgrave.crr.1550047.

Gardberg, N. A., \& Fombrun, C. J. (2006). Corporate citizenship: Creating intangible assets across institutional environments. Academy of Management Review, 31 (2), 329-346. doi 10.5465/AMR.2006.20208684.

Global Slavery Index. (2016). The Global Slavery Index 2016. Retrieved from https://www.globalslaveryindex.org/index/.

Greyser, S. A. (2009). Corporate brand reputation and brand crisis management. Management Decision, 47(4), 590-602. doi 10.1108/00251740910959431.

Gupta, M., \& Hodges, N. (2012). Corporate social responsibility in the apparel industry: an exploration of Indian consumers' perceptions and expectations. Journal of Fashion Marketing and Management: An International Journal, 16(2), 216-233. doi 10.1108/13612021211222833.

Hemingway, C. A., \& Maclagan, P. W. (2004). Managers' personal values as drivers of corporate social responsibility. Journal of Business Ethics, 50(1), 33-44. doi 10.1023/B:BUSI.0000020964.80208.c9.

Jamali, D., \& Neville, B.A. (2011). Convergence versus divergence of CSR in developing countries: an embedded multi-layered institutional lens. Journal of Business Ethics, 102 (2), 599-621. doi 10.1007/s10551-011-0830-0.

Machado, C. A. P., Filho (2002). Responsabilidade social corporativa e a criação de valor para as organizações: um estudo multicascos. Tese de doutorado, Universidade de São Paulo, São Paulo, Brasil.

Machado Filho, C. A. P., \& Zylbersztajn, D. (2004). A empresa socialmente responsável: o debate e as implicações. Revista de Administração, 39 (3), 242-254. Mascarenhas, A. O., Gonçalves-Dias, S. L., \& Baptista, R. M. (2015). Elementos para discussão da escravidão contemporânea como prática de gestão. Revista de Administração de Empresas, 55(2), 175-187. doi 10.1590/ S0034-759020150207.

Matten, D., \& Moon, J. (2008). "Implicit" and “explicit" CSR: a conceptual framework for a comparative understanding of corporate social 
responsibility. Academy Management Review, 33(2), 404-424. doi 10.5465/ AMR.2008.31193458.

Ministério do Trabalho e Emprego. (2011). Manual de combate ao trabalho em condições análogas às de escravo. Retrieved from http://portal.mte.gov.br/data/ files/8A7C816A350AC88201350B7404E56553/combate\%20trabalho\%20 escravo\%20WEB.PDF.

Miraglia, L. M. M. (2008). Trabalho escravo contemporâneo: conceituação à luz do princípio da dignidade da pessoa humana. Dissertação de Mestrado, Pontifícia Universidade Católica de Minas Gerais, Belo Horizonte, Brasil.

Mohr, L. A., Webb, D. J., \& Harris, K. E. (2001). Do consumers expect companies to be socially responsible? The impact of corporate social responsibility on buying behavior. Journal of Consumer Affairs, 35(1), 45-72. doi 10.1111/j.1745-6606.2001.tb00102.x.

Monteiro, L. A., \& Fleury, S. (2014). Elos que libertam: redes de políticas para erradicação do trabalho escravo contemporâneo no Brasil. Organizações $\mathcal{E}$ Sociedade, 21 (69), 255-274. doi 10.1590/S1984-92302014000200004.

Moro Junior, A. A. (2011). O trabalho decente no contexto de elevação dos direitos sociais à condição de direitos fundamentais. Revista de Direito Internacional, 8(2), 71-93. doi 10.5102/rdi.v8i2.1551.

North, D. C. (1990). Institutions, institutional change and economic performance. Cambridge: Cambridge University Press.

Oliveira, C. R., Valadão-Junior, V. M., \& Miranda, R. (2013). Culpada ou inocente? Comentários de internautas sobre crimes corporativos. Revista de Administração de Empresas, 53(6), 617-628. doi 10.1590/S0034-759020130609.

Organização Internacional do Trabalho. (2005). Uma aliança global contra o trabalho forçado. Retrieved from http://www.oit.org.br/sites/all/forced labour/oit/relatorio/relatorio_global2005.pdf.

Organização Internacional do Trabalho. (2014). Profits and Poverty: the Economics of Forced Labour. Retrieved from http://www.oitbrasil.org.br/sites/ default/files/topic/gender/doc/trabalhoescravointegra_1135.pdf.

Pedersen, E. R. G., \& Gwozdz, W. (2014). From resistance to opportunityseeking: strategic responses to institutional pressures for corporate social responsibility in the Nordic fashion industry. Journal of Business Ethics, 119(2), 245-264. doi 10.1007/s10551-013-1630-5.

Phillips, N., \& Sakamoto, L. (2012). Global production networks, chronic poverty and 'slave labour' in Brazil. Studies in Comparative International Development, 47(3), 287-315. doi 10.1007/s12116-012-9101-z. 
Powell, B., \& Skarbek, D. (2006). Sweatshops and third world living standards: are the jobs worth the sweat? Journal of Labor Research, 27(2), 263-274. doi 10.1007/s12122-006-1006-z.

Repórter Brasil. (2012). Especial: flagrantes de trabalho escravo na indústria têxtil no Brasil. Retrieved from http://reporterbrasil.org.br/2012/07/especialflagrantes-de-trabalho-escravo-na-industria-textil-no-brasil/.

Repórter Brasil. (2015). Pacto nacional pela erradicação do trabalho escravo no Brasil. Retrieved from http://www.reporterbrasil.org.br/pacto/conteudo/ view/4.

Rocha, G. (2009). A formação das agendas sociais privadas: um estudo a partir da questão do trabalho escravo contemporâneo. Dissertação de Mestrado, Universidade Federal Fluminense, Rio de Janeiro, Brasil.

Scott, W. R. (2001). Institutions and Organizations (2nd ed.). London, United Kingdom: Sage.

Veludo-de-Oliveira, T., Mascarenhas, A., Tronchin, G., \& Baptista, R. (2014). Consumo socialmente responsável no varejo da moda: analisando a intenção dos consumidores de deixar de comprar de empresas denunciadas por escravidão contemporânea. Revista de Gestão Social e Ambiental, 8(2), 63-75. doi 10.5773/rgsa.v8i2.961.

Viana, M. T. (2006). Trabalho escravo e "lista suja": um modo original de se remover uma mancha. Revista do Tribunal Regional do Trabalho da $3^{a}$ Região, 44(74), 189-215.

\section{$\int$ ABOUT THE AUTHORS}

\section{TOBIAS COUTINHO PARENTE}

$\mathrm{PhD}$ Student from the Department of Business Administration,

Universidade de São Paulo (USP).

Master in Administration from the Department of Business Administration,

Universidade de São Paulo (USP).

Av. Professor Luciano Gualberto, 908, Cidade Universitária - São Paulo - SP - Brasil - CEP

05508-010

E-mail: tobiascoutinho@gmail.com 


\section{ก}

Tobias Coutinho Prente, Angela Christina Lucas, Rafaela Almeida Cordeiro

\section{ANGELA CHRISTINA LUCAS}

$\mathrm{PhD}$ in Administration from the Department of Business Administration,

Universidade de São Paulo (USP).

Professor at the Department of Business Administration,

Centro Universitário FEI.

Av. Humberto de Alencar Castello Branco, 3972, Assunção, São Bernardo do Campo - SP Brasil - CEP 09850-305

E-mail: angelalucas1229@gmail.com

\section{RAFAELA ALMEIDA CORDEIRO}

$\mathrm{PhD}$ student from the Postgraduate Program in International Management,

Escola Superior de Propaganda e Marketing (ESPM).

Master in Administration from the Postgraduate Program in International Management,

Escola Superior de Propaganda e Marketing (ESPM).

Rua Álvaro Alvim, 123, Vila Mariana, São Paulo - SP - Brazil - CEP 04018-010

E-mail: ralmeidacordeiro@gmail.com 